\title{
KNOWLEDGE OF PRIMARY HEALTH CARE NURSES IN PROVIDING FIRST AID IN LIFE-THREATENING EMERGENCIES
}

\section{WIEDZA PIELĘGNIAREK PODSTAWOWEJ OPIEKI ZDROWOTNEJ Z ZAKRESU UDZIELANIA PIERWSZEJ POMOCY W NAGŁYCH STANACH ZAGROŻENIA ŻYCIA}

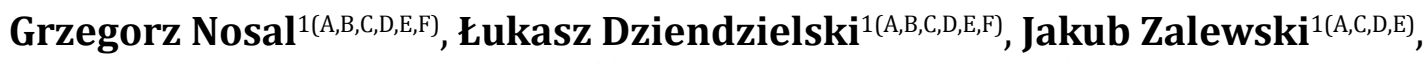 \\ Jerzy Zagórski ${ }^{2(E)}$, Izabela Wróblewska ${ }^{3,4(C, D, E)}$ \\ ${ }^{1}$ Państwowa Medyczna Wyższa Szkoła Zawodowa w Opolu \\ ${ }^{2}$ Państwowa Szkoła Wyższa im. Papieża Jana Pawła II w Białej Podlaskiej \\ ${ }^{3}$ Uniwersytet Medyczny im. Piastów Śląskich we Wrocławiu \\ ${ }^{4}$ Karkonoska Państwowa Szkoła Wyższa w Jeleniej Górze
}

Nosal G., Dziendzielski Ł., Zalewski J., Zagórski J., Wróblewska I. (2017), Knowledge of primary health care nurses on providing first aid in life-threatening emergencies. Rozprawy Społeczne, 11 (2), s. 62-66.

Wkład autorów:

A. Zaplanowanie badań

B. Zebranie danych

C. Dane - analiza i statystyki

D. Interpretacja danych

E. Przygotowanie artykułu

F. Wyszukiwanie i analiza

literatury

G. Zebranie funduszy
Tabele: 0

Ryciny: 3

Literatura: 19

Otrzymano: 06.09.2016

Zaakceptowano: 17.02 .2017

\begin{abstract}
Summary
Introduction. A primary health care nurse is equipped with skills obtained during primary education ( $1^{\text {st }}$ degree studies), which can be additionally widened owing to post-graduate education. The aim of the study is to assess the knowledge of nurses working in primary health care centres in Opole, Poland, with reference to providing first aid in life-threatening emergencies occurring outside their working place.

Materials and methods. In the quantitative studies carried out in 2015, the method of a diagnostic poll was applied. It consisted in performing the authors' own test referring to knowledge on providing first aid. The research comprised 45 nurses in 11 primary health care centres in Opole, Poland.

Results. The responders presented a medium level of knowledge concerning basic life support and automatic external defibrillation (54\%) as well as providing help to a non-breathing child $(55 \%)$. As few as $1 / 3$ of the responders knew how to proceed in a communication accident, and $1 / 4$ did not have verify their skills after graduation through taking part in post-graduate education. The total of $40 \%$ of the responders had provided first aid in life-threatening emergencies occurring outside their working place.

Conclusions. The level of post-graduate education should be raised along with the number of regular training sessions in the working place with reference to providing first aid in life-threatening emergencies.
\end{abstract}

Keywords: nurse, first aid, life-threatening

\section{Streszczenie}

Wstęp. Pielęgniarka POZ jest zobowiązana do udzielania pierwszej pomocy zgodnie z uzyskanymi podczas kształcenia podstawowego kwalifikacjami, które może poszerzać dzięki kształceniu podyplomowemu. Cel pracy: ocena wiedzy pielęgniarek pracujących w przychodniach POZ na terenie miasta Opola z zakresu udzielania pierwszej pomocy w nagłych stanach zagrożenia życia występujących poza miejscem pracy.

Materiał i metody. W badaniach przeprowadzonych w 2015 r. została wykorzystana metoda sondażu diagnostycznego (autorski test). Obejmował on wiedzę z zakresu udzielania pomocy na poziomie Kwalifikowanej Pierwszej Pomocy. Badania przeprowadzono wśród 45 pielęgniarek w 11 opolskich przychodniach POZ.

Wyniki. Ankietowani wykazali się średnią wiedzą z zakresu podstawowych zabiegów resuscytacyjnych i automatycznej defibrylacji zewnętrznej (54\%), a także udzielania pomocy nieoddychającemu dziecku (55\%). Jedynie 1/3 respondentów znała zasady postępowania w wypadku komunikacyjnym, a $1 / 4$ nie weryfikowała swoich umiejętności po uzyskaniu dyplomu. Jednocześnie $40 \%$ badanych udzielało pierwszej pomocy w stanach zagrożenia życia poza miejscem pracy.

Wnioski. Należy zwrócić uwagę na jakość dotychczasowego kształcenia podyplomowego oraz organizację regularnych szkoleń w miejscu pracy z zakresu udzielania pomocy w nagłych stanach zagrożenia życia.

Słowa kluczowe: pielęgniarka, pierwsza pomoc, stan zagrożenia życia

Adres korespondencyjny: Izabela Wróblewska, Uniwersytet Medyczny im. Piastów Śląskich we Wrocławiu, Wydział Nauk o Zdrowiu, Zakład Gerontologii, ul. Bartla 5, 50-996 Wrocław, e-mail: izabela.wroblewska@umed.wroc.pl, tel. 717841813

Copyright by: Państwowa Szkoła Wyższa im. Papieża Jana Pawła II w Białej Podlaskiej, Grzegorz Nosal, Łukasz Dziendzielski, Jakub Zalewski, Jerzy Zagórski, Izabela Wróblewska

Czasopismo Open Access, wszystkie artykuły udostępniane są na mocy licencji Creative Commons Uznanie autorstwa-użycie niekomercyjne-na tych samych warunkach 4.0 Międzynarodowe (CC BY-NC-SA 4.0, http://creativecommons.org/licenses/by-nc-sa/4.0/). 


\section{Introduction}

The Polish legal regulations imply that nurses working in primary health care centres must fulfil specific conditions with regard to post-graduate education: among others, to complete specialist training or qualification courses (Act of August 27, 2004).

Education of nurses in Poland is based on the Bologna Accord of 1999 (Collins and Hewer 2014) and on the suitable acts and ordinances of the Minister of Health. The process begins with bachelor studies, and the legal obligation to educate nurses means the opportunity to continue education in the form of master or doctoral studies, as well as during supplementary, specialist or qualification courses, and specialist education within a chosen realm (Act of July 15, 2011). A graduate of the $1^{\text {st }}$ degree studies should possess knowledge and skills allowing to diagnose life-threatening emergencies in patients of any age (Ordinance of the Minister of Science; Syllabus). In the course of the $2^{\text {nd }}$ degree studies, nurses develop the skills mentioned above and improve resuscitation procedures owing to the courses in 'emergency nursing' and 'intensive therapy and nursing in intensive care' (Ordinance of the Minister of Science; Study plan). Post-graduate training allows to develop knowledge within particular specialties, including first aid (Centre for Post-graduate 2015a, 2015b).

The Polish law regulates an obligation to provide aid to all injured people. It imposes a duty on each citizen to help those in a health-threatening emergency (Act of September 8, 2006). The regulations unambiguously demand that medical personnel undertake high quality resuscitation procedures, in accordance with the possessed qualifications (Act of July 15, 2011; Żaba et al. 2007). Violation of these rules by a nurse results in civil, penal, and professional responsibility. The Penal Code implies that lack of providing aid to a person in a health-threatening emergency is referred to as a criminal offence and may result in a fine penalty or imprisonment for up to three years (Act of June 6, 1997). According to the Petty Offences' Code, in the case of a communication accident, lack of providing help is an offence additionally endangered with withdrawal of the driving licence (Act of May 20, 1971).

\section{Aim of the study}

The aim of the present research was to assess the knowledge of nurses working in primary health care centres in Opole, Poland, with reference to providing first aid in life-threatening emergencies occurring outside their working place.

\section{Material and methods}

In the quantitative studies carried out in 2015, the method of a diagnostic poll was applied. It consisted in performing the authors' own test referring to knowledge on providing first aid in pre-hospital settings outside the nurses' working place. The participant nurses were employed in primary health care centres in Opole, Poland.

The research comprised $45(100 \%)$ nurses in 11 primary health care centres in Opole, Poland, from among 17 available centres. Directors of 6 primary health care centres did not agree to take part in the study.

The majority of responders were women $(\mathrm{n}=42$; 93\%); 3 (7\%) participants did not provide information on their sex. The responders were mainly aged 50-59 years $(\mathrm{n}=16 ; 36 \%)$; the subsequent age ranges were $40-49$ years $(n=15 ; 33 \%), 30-39$ years $(n=6 ; 13 \%)$, under 30 years $(n=4 ; 9 \%)$, and $60-69$ years $(n=3 ; 7 \%)$.

Almost half of the study subjects $(n=22 ; 49 \%)$ represented secondary education, 19 (42\%) participants had graduated from $1^{\text {st }}$ degree studies, and $3(7 \%)$ had $2^{\text {nd }}$ degree studies diplomas. Additionally, 30 (66\%) nurses had completed a specialization or courses demanded for primary health care nurses. In this group, 5 (11\%) responders had a specialization or a qualification course completed in emergency/anaesthetic nursing and intensive therapy, and 4 (9\%) had taken a specialist course in cardiopulmonary resuscitation.

\section{Results}

In the study, respondents were asked to rate their knowledge of first aid in the 10-point scale (Figure 1).

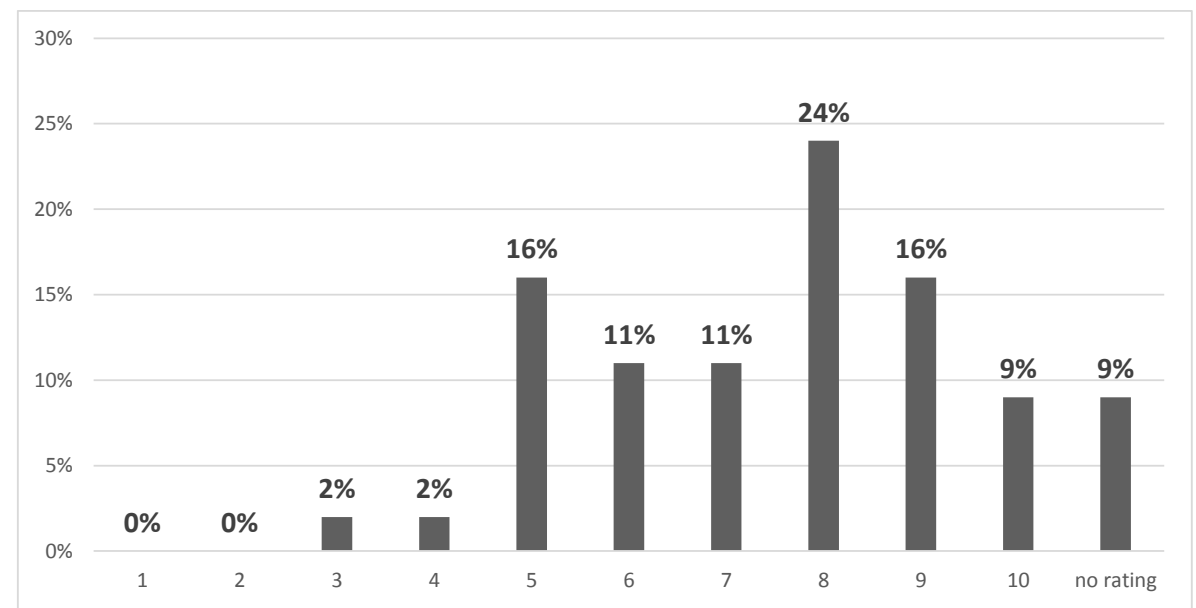

Figure 1. Subjective assessment of the respondents concerning skills assistance ("weak" 1-10 "well") 
The majority of the responders correctly indicated safety assessment as the first step of providing aid ( $\mathrm{n}$ $=28 ; 62 \%$ ), as well as specified the ABC procedure as the evaluation of the patient status with regard to the respiratory system patency (airway), breathing, and circulation ( $n=43,96 \%)$. The subjects were asked to point at the actions that were not elements of the airway management procedure. The total of $60 \% \mathrm{n}=$ 27) properly indicated passive oxygen therapy. Most responders $(n=37 ; 82 \%)$ would accurately select the oropharyngeal tube size, by aligning it between the ear lobe and the mouth angle of the injured person. The same number of participants answered that an oropharyngeal tube could be applied in deeply unconscious patients only.

In the basic life support (BLS) algorithm, a vast majority of the subjects $(n=40 ; 89 \%)$ indicated the correct ratio of 30 chest compressions to 2 rescue breaths. From among all the responders, 12 (27\%) knew that the accurate chest compression depth was
5-6 cm, and $30(67 \%)$ would apply cardiopulmonary resuscitation with the chest compression frequency of $100-120 \bullet \mathrm{min}^{-1}$.

In the test questionnaire, the study subjects were presented a figure showing four possibilities of positioning defibrillator electrodes. They were asked to answer if all the arrangements were allowable. The total of 15 (33.5\%) responders accepted all the presented versions. The majority $(n=41 ; 91 \%)$ defined the 'AED' abbreviation as 'automated external defibrillator,' 'automated electric defibrillator,' or 'all exploitation defibrillator.'

The participants were also asked to indicate the sequence of providing first aid to neonates and infants in the case of choking, when the child's cough turns out ineffective. In 20 cases (44\%) the answer was that one should interchangeably perform 5 strokes in the interscapular region and 5 compressions in the lower sternum area (Figure 2).

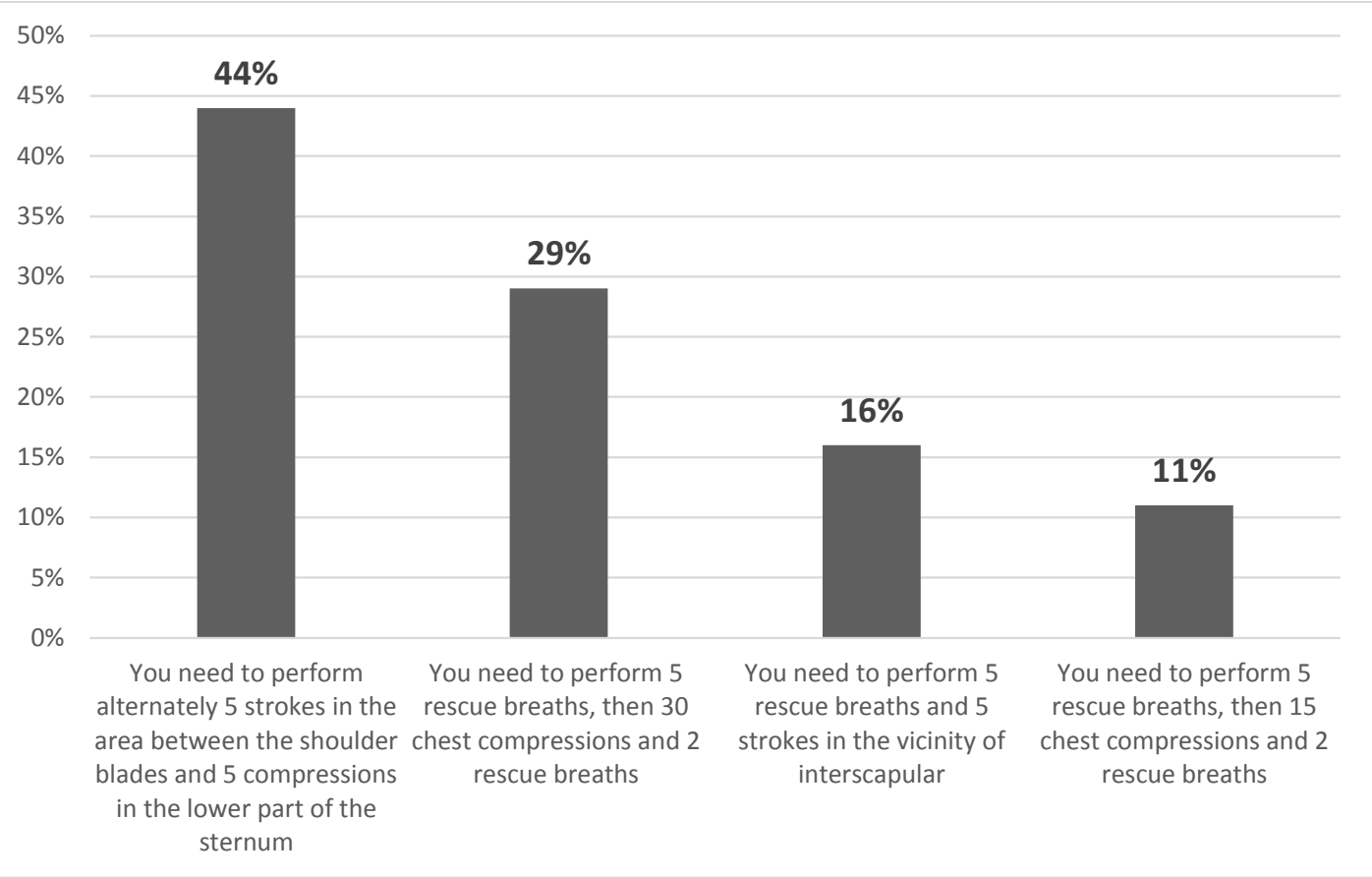

Figure 2. Knowledge of the respondents concerning aid for choking newborns and infants

In respiratory arrest in a 3-year-old child, $30(66.5 \%)$ responders would modify the BLS algorithm, performing 5 rescue breaths before the cardiopulmonary resuscitation (Figure 3).

From among the studied nurses, 39 (86.5\%) maintained that the first signs of anaphylactic shock were tachycardia and hypotension; 31 (69\%) declared that capillary refill should take less than 2 seconds.

According to 35 (78\%) responders, pink skin integuments in an unconscious and not breathing patient suggest carbon monoxide poisoning. In turn, $27(60 \%)$ nurses would manage an emphysema (puncture wound) in the upper dorsal region with a vent dressing. A closed fracture would be managed in accordance with Pott's rule by 41 (91\%) subjects.

Almost half of the responders $(n=20 ; 44 \%)$ correctly stated that protecting a communication accident site out of a built-up area, on a road with a speed limit of $90 \mathrm{~km} / \mathrm{h}$, should include parking the vehicle on the own driving lane and turning the wheels to the right, followed by turning on the emergency lights, putting on a reflective vest, and displaying a warning triangle in the distance of 3050 meters away from the accident site. 


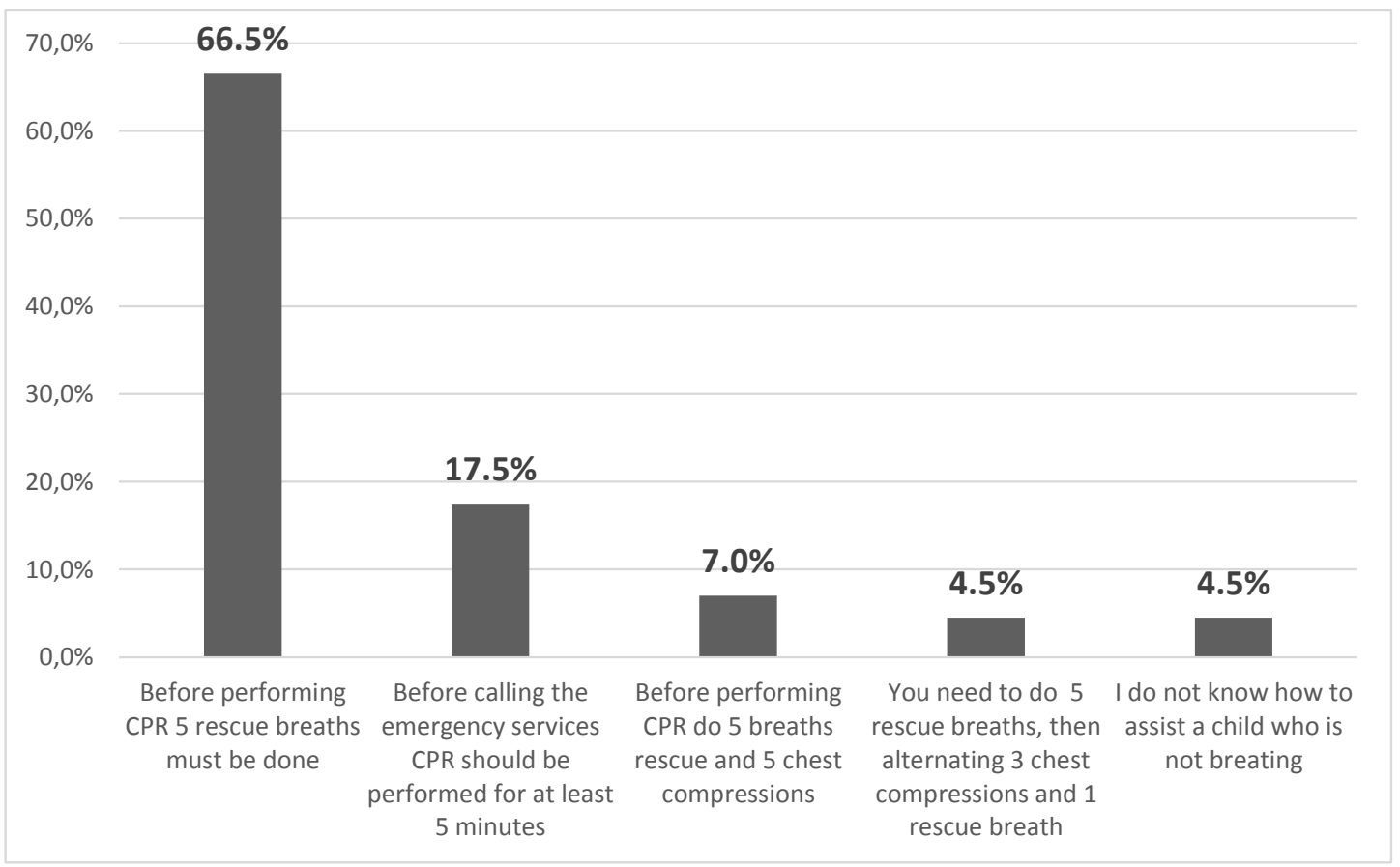

Figure 3. Respondents' knowledge of CPR algorithm in children

Few subjects ( $\mathrm{n}=11 ; 24.5 \%$ ) would appropriately protect the communication accident site and assess the safety of the people injured in the vehicles as the first action, and then analyse the number and status of the wounded, call emergency service, and provide first aid (beginning with those with trauma, at last resuscitating those who do not breathe).

The study performed also proved that 27 (60\%) responders had taken part in a training for nurses concerning first aid or emergency medical condition management, organized by their parental institution; however, $10(22 \%)$ had not completed any training (either in the working place or outside it).

All the subjects $(n=45 ; 100 \%)$ agreed with the need of regular training (in $0.5-5$ years intervals) for the nursing staff with regard to providing first aid or managing emergency medical conditions. The majority ( $\mathrm{n}=27 ; 60 \%)$ declared that they had never occurred to provide first aid outside the working place; the rest $(n=18 ; 40 \%)$ happened to do it from a few to over a dozen times.

\section{Discussion}

The study performed among students of nursing (non-stationary studies) at Opole Public Medical Higher Professional School and professionally active nurses shows that the nurses and students answered the questions concerning BLS at a similar level (Kupczyk et al. 2012). The obtained data also support the results of a research carried out in 2008 and 2009 among physicians in a north-central Sri Lanka province, pointing out the significance of arranging regular training in resuscitation. It turns out that training organized according to the standards of the International Liaison Committee on Resuscitation (ILCOR) considerably increases the knowledge and skills of the participants. As a result, the qualifications relating to consciousness assessment, as well as restoring respiratory system patency and chest compressions depth rise by 61 and $79 \%$, respectively (Rajapakse et al. 2013). It is argued that BLS training should be repeated every 12-24 months. Those who may more frequently encounter cardiac arrest cases should be trained more often, as unpractised skills decrease within 3-12 months (Greif et al. 2015). Moreover, research performed among nurses in Jordan proves that training which allows to practise BLS skills in simulated sudden cardiac arrest situations significantly improves the knowledge and competence of the personnel (Toubasi et al. 2015).

The results obtained in the presented study remain concordant with the outcomes of an analysis carried out in the Podlaskie province, published in 2004. They indicate that almost all the responders admit a constant need of training in the domain under discussion. As few as a half of the studied nurses had completed a post-graduate training in the field. A mere half could also correctly manage a nonbreathing patient; a vast majority, in turn, declared a suitable aid to a person with a foreign body stabbed in the chest (Baszeń et al. 2004).

Scientists from the Medical University of Warsaw indicate that insufficient first aid knowledge of the nursing staff results from inadequate number of hours of education in this realm as assumed in the nursingstudy programme. They point out that reliable 
education of nurses in the field under discussion may decrease their fear of life-saving procedures and contribute to the prestige of the profession. These conclusions follow a study performed among first year students of master non-stationary studies of nursing. The research analysis proved that almost half of the subjects had never taken part in a first aid training at their working place or provided first aid in a life-threatening emergency. Over a half correctly defined the differences between resuscitation and advanced cardiac life support, and knew the appropriate chest compression depth; $3 / 4$ of the responders recognized the sequence of the chain of survival links and properly presented automated external defibrillation (Olejniczak 2013).

Other studies, performed in the Opolskie province, demonstrated that a vast majority of the nursing personnel could correctly assess and protect an accident site, as well as perform cardiopulmonary resuscitation. In turn, policemen, who are responsible of providing qualified first aid, presented a ca. 50\% level of knowledge. Both the nursing staff and the policemen answered the questions concerning trauma management at the level of $60 \%$. The set of questions referring to life-threatening emergencies revealed that the policemen's knowledge was slightly lower than that of the nurses $(2 / 3$ and $3 / 4$ correct answers, respectively) (Płaczek 2011).

\section{Conclusions}

1. The nurses' knowledge with regard to providing first aid turns out insufficient; the same refers to the repeatability and quality of training offered to the primary health care personnel.

2. The level of post-graduate education should be raised, as well as the number of regular training in the working place with reference to providing first aid in life-threatening emergencies.

3. It should be advised that the improvement of first aid education is also a responsibility of primary health care employers.

\section{References:}

1. Act of August 27, 2004 on healthcare benefits financed from public resources.

2. Act of July 15, 2011 on the professions of nurse and midwife.

3. Act of June 6, 1997, Penal Code, Art. $162 \S 2$.

4. Act of May 20,1971, Petty Offences' Code, Art. 93.

5. Act of September 8, 2006 on Public Emergency Medical Service.

6. Baszeń K., Jankowiak B., Krajewska-Kułak E., Łukaszuk C. (2004), Poziom wiedzyi umiejętności pielęgniarek z zakresu udzielania pierwszej pomocy. Pieleggniarstwo XXI wieku, 3 (8), p. 83-87.

7. Centre for Post-graduate Education of Nurses and Midwives (2015a), Program for the qualifying course for nurses in family nursing, paediatric nursing, palliative care, long-term care, workers' health care, and educational and upbringing environment. Warsaw.

8. Centre for Post-graduate Education of Nurses and Midwives (2015b), Program for the specialist training for nurses in family nursing, paediatric nursing, palliative care, long-term care, and workers' health care. Warsaw.

9. Collins S., Hewer I. (2014), The impact of the Bologna process on nursing higher education in Europe: a review. Int. J. Nurs. Stud., 51 (1), p. 150-156.

10. Greif R., Lockey A.S., Conaghan P., Lippert A., De Vries W., Monsieurs K.G. (2015), European Resuscitation Council Guidelines for Resuscitation 2015: Section 10. Education and implementation of resuscitation. Resuscitation, 95, p. 288-301.

11. Kupczyk M., Lukasczyk I., Zalewski J. (2012), Wiedza studentów pielęgniarstwa PMWSZ w Opolu dotycząca zasad udzielania pierwszej pomocy w przypadku nagłego zatrzymania krażenia, In: A. Steciwko, M. Wojtal, D. Żurawicka (eds.), Pielęgnacyjne i kliniczne aspekty opieki nad chorymi. Wybrane zagadnienia. Vol. 5, Continuo, Wrocław, p. 160-168.

12. Olejniczak D., Miciuk D., Religioni U. (2013), Ocena stanu wiedzy studentów Warszawskiego Uniwersytetu Medycznego na kierunku pielegniarstwo na temat udzielania pierwszej pomocy przedmedycznej. Piel. Zdr. Publ., 3 (2), p. 101-110.

13. Ordinance of the Minister of Science and Higher Education of May 9, 2012 on the educational standards for the following study specializations: medicine, dental medicine, pharmacy, nursing, and midwifery.

14. Płaczek A. (2011), Doskonalenie zawodowe policjantów w zakresie udzielania pierwszej pomocy, In: S. Słowińska (ed.), Dyskursy młodych andragogów. Oficyna Wydawnicza Uniwersytetu Zielonogórskiego, Zielona Góra, p. 121-132.

15. Rajapakse B.N., Neeman T., Dawson A.H. (2013), The effectiveness of a 'train the trainer' model of resuscitation education for rural peripheral hospital doctors in Sri Lanka. PLoS One, 8 (11), e79491.

16. Study plan since academic year 2016/2017, nursery specialization, Opole Public Medical Higher Professional School, $2^{\text {nd }}$ degree stationary studies. Approved with Resolution No. 93 of the Nursery Institute Board of November 18, 2014.

17. Syllabus for the $3^{\text {rd }}$ year of nursery specialization, $1^{\text {st }}$ degree studies, Opole Public Medical Higher Professional School, academic year 2016/2017.

18. Toubasi S., Alosta M.R., Darawad M.W., Demeh W. (2015), Impact of simulation training on Jordanian nurses' performance of basic life supports kills: a pilot study. Nurse Educ. Today, 35 (9), p. 999-1003.

19. Żaba C., Żaba Z., Orłowski M. et al. (2007), Prawno-medyczne problemy udzielania pierwszej pomocy. Arch. Med. Sąd. Krym., 57, p. 128-133. 